\title{
MORPHOLOGICAL CHARACTERIZATION AND CHEMICAL ANALYSIS STUDY OF SOME COMMON DATE PALM CULTIVARS GROWN IN ISMAILIA REGION \\ Mostafa A. F.; ${ }^{\star}$ M. S. Beltagi ; H. M. Hassan ${ }^{\star}$ and A. M. El Assar ${ }^{*}$ \\ "Botany Department, Faculty of Science, Suez Canal University, Ismailia, Egypt. \\ "*Tropical Fruits \& Date Palm Research Department, Horticulture Research Institute, Giza, Egypt. \\ E-Mail address: a-assar@hotmail.com
}

\begin{abstract}
This comparative study was carried out during 2001 season at the Botany Department, Faculty of Science, Suez Canal University, Ismailai, Egypt. Six cultivars of the most common dates were submitted to evaluation (Agglany, Ammry, Bint Aisha, Hayani, Samany and Zaghloul). The study involved the measurements of morphological characteristics of palm trees and date fruits as well as chemical measurements of fruits at maturation (marketable) stage. The minimum trunk diameter was recorded with Ammry $(21 \mathrm{~cm})$ while the maximum trunk diameter was recorded with Hayani $(31 \mathrm{~cm})$. The number of bunches per palm tree varied from 8.22 with Samany to 15.33 bunches with Ammry. The number of fruits on each stalk ranged from 11.63 for Zaghloul to 19.04 fruits / stalk for Agglany. The smallest weight of fruit stalk was $166.04(\mathrm{~g})$ for Bint Aisha, while the greatest weight of fruit stalk was 304.22 (g) for Samany. The length of fruit stalk varied from a shortest of $0.57(\mathrm{~m})$ in Zaghloul to a longest of $1.82(\mathrm{~m})$ in Agglany. The maximum number of fruit stalks/ bunch was recorded with Agglany (118.00 stalks/bunch), however no significant differences occurred among all other five studied cultivars. Agglany was superior to all studied cultivars concerning the total yield $(333.95 \mathrm{~kg} / \mathrm{palm})$, while Zaghloul was had the lowest total yield (141.77 kg / palm). Samany had seemed as a major cultivar and the data indicated that it has distinctive morphological characteristics such as: the highest blade width at both the basal and middle regions, spine zone length, number of spines, length of spine, pinna length at the middle region of the blade, width of pinna at the middle region of the blade, weight of leaf, weight of fruit stalk, fruit diameter at the middle region, fruit weight, width of inflorescence spathe, and diameter and weight of seed. The Agglany and Ammry cultivars were related to each other in their morphological attributes. They shared approximately the same diameter of palm trunk, number of fruits in each stalk, weight of fruit stalk, blade width along the main rachis, length of the spine zone, length of pinnae zone, number of pinnae on both sides of the rachis, spine length, width of pinna at the apical region of the blade, length/width ratio of pinna at the basal region of the blade, pinna thickness, diameter of fruit at the apical region, and length of inflorescence spathe. Likewise, the study indicated that the Hayani and Bint Aisha cultivars have many distinguishing morphological attributes. They have similar trunk diameters, number of fruit bunches for each tree, number of stalks in each fruit bunch, number of fruits for each stalk, leaf length, blade width along the main rachis, length of spine zone, length of pinnae zone, number of spines on both sides of the rachis, spine length, length/ width ratio of the pinna at the middle region of the blade, width of pinna at the middle region of the blade, pinna thickness, weight of leaf. and fruit colour. On the other hand, the most significant and distinguishable morphological attributes that were found in Zaghloul cultivar, which differed from all other studied cultivars. It had the shortest fruit stalk, lowest number of spines on both sides of the rachis, the highest number of pinnae on both sides of the
\end{abstract}


Mostafa A. F. et al.

rachis, shortest pinna length at the basal region of the blade, shortest pinna width at the apical region of the blade, highest length/ width ratio of pinna at the apical region of the blade, bright red colour fruits, highest diameter at both the base and the apex of fruit, longest fruit length, longest spathe inflorescence, and highest spathe length/ width ratio. Statistical analysis of total sugars content showed significant differences among all studied cultivars, where it ranged between $48.25 \%$ in Samany to $77.25 \%$ in Ammry. Regarding fruit quality traits, it was found that the total acidity percentage differed significantly among the studied cultivars at the ripening stage. Ammry had the lowest acidity percentage (0.04\%) and Zaghloul had the highest value $(0.12 \%)$. The values of crude protein ranged from $1.6 \%$ in Zaghloul to $2.75 \%$ in Bint Aisha. Concerning the macro elements analysis, the data showed that the most abundant element was potassium. Magnesium content values ranged from $0.11 \mathrm{ppm}$ in Samany to $0.16 \mathrm{ppm}$ in Agglany. Among the trace elements, the data analysis showed that iron was the main element showing highly significant differences among all studied cultivars. Iron content values ranged from 30.24 ppm in Ammry to 54.94 ppm in Bint Aisha.

\section{INTRODUCTION}

Date palm (Phoenix dactylifera L.) is amongst of the few plant species that have developed into important fruit crops and become connected with human life. The exact origin of the date palm has been lost in history, but evidence of date palm cultivation goes as far back as 4000 B.C. in southern Iraq. References to date palms have also been found in Ancient Egypt, and there seems to be a consensus that the earliest form of date palm cultivation coincided with the oldest civilizations and originated in North - East Africa, stretching north east into the delta of the Euphrates and Tigris (Barreveld, 1993).

The present situation in the world as a net result of these historical developments is that the date palm is distributed throughout the Middle East, North Africa, areas of South Africa, SW USA, Central \& South America and even Southern Europe (Spain \& Italy). The total number of date palm trees is approximately 105 million, covering an area of 800.000 hectares (Al-Yhya, 1995). Two thousand or more various cultivars of date palm are known to exist all over the world, but only a few important ones have been evaluated for their agronomic performance and fruit quality (Al-Hooti et al., 1997).

The date palm fruits provide a concentrated energy food, which could be easily stored for long periods. Dates are considered the most popular fruit not only in Egypt, but also all over the Arab countries. In addition, the date palm tree also yields a variety of products for use in agricultural production and for domestic utensils, and practically all parts of the palm have a useful purpose. Egypt comes in the front regarding the numbers of date palm trees among the Arab countries and is the leading date fruits producing area in the world, with an annual production of 1,113,270 tons in 2002 that accounted for $17.78 \%$ of world wide date production (FAO Statistics, 2003). The Ismailia Governorate, ranking for its soft and semi-dry date palm cultivars, has 436.894 female palms with a total yearly production of 43.379 tons (Ministry of Agriculture, 2001). 


\section{MATERIALS AND METHODS}

This study was run during 2001 season at the Botany Department, Faculty of Science, Suez Canal University, Ismailia, Egypt to verify the palm tree attributes and leaf morphological characteristics as well as fruit quality and mineral analysis of the most common Egyptian dates in the Ismailia region. Six cultivars were submitted for this investigation. They were Agglany, Ammry, Bint Aisha, Hayani, Samany, and Zaghloul. Three replicates of each cultivar from three different sites were collected. Samples of mature leaves were taken from the region above fruit bunches and the stalks of mature fruits were collected at marketing time. Then, samples were labeled and transferred to the laboratory for further morphological and chemical analysis. Palm trunk diameter $(\mathrm{cm})$ was measured at breast height level $(1.5 \mathrm{~m}$, approximately). The number of bunches/ palm tree, mean number of fruits in each stalk, fresh weight of a fruit stalk $(\mathrm{g})$, length of fruit stalk $(\mathrm{m})$; and the number of fruit stalks in each bunch were recorded as morphological characters. For leaf morphological characters, measurements such as length $(\mathrm{m})$; width of blade $(\mathrm{m})$ at basal, middle, and apical regions; spine zone length $(\mathrm{cm})$; pinnae zone length $(\mathrm{cm})$; number of spines on both sides of rachis; number of pinnae on both sides of rachis; spine length $(\mathrm{cm})$; pinna length at basal, middle, and apical region of blade $(\mathrm{cm})$; pinnae zone/ spines zone ratio; width of pinna at basal, middle, and apical region of blade $(\mathrm{cm})$; ratio of pinna length: pinna width; thickness of 10 pinnae $(\mathrm{mm})$; number of pinnae at blade apex; the angle between pinna and rachis; and the leaf fresh weight $(\mathrm{kg})$ were taken. For fruits, measurements included length; diameter of base, middle, and apical districts $(\mathrm{cm})$ by using vernier caliper; fruit weight average (g); and fruit colour. Spadix (spathe) morphology characters were recorded such as length, width, spathe length / width ratio, and spathe indumentum (moderately or sparsely fuzz). Also, the seeds were removed and morphological characters (length \& diameter $(\mathrm{cm})$, weight $(\mathrm{g})$, and the position of pit) were recorded. Various quality attributes and mineral analysis of fruits were determined according to the methods of the Official Analytical Chemists (1985). These measurements included total sugars (\%), total solids $(\%)$, total titratable acidity (\%), $\mathrm{pH}$ value $(5 \mathrm{~g}$ in $100 \mathrm{ml}$ diluted water), and crude protein $(\mathrm{N} \times 6.25)(\%)$. Total nitrogen content was performed by using the Micro-Kjeldahl method (Pregl, 1945). Also, minerals were estimated ( $N$, $\mathrm{P}, \mathrm{K}, \mathrm{Mg}, \mathrm{Fe}, \mathrm{Mn}, \mathrm{Zn}$ and $\mathrm{Cu}$ ) by using a flame photometer for potassium and sodium and by using a Perkin Elmer Atomic Absorpation Spectrophotometer for others (Black et al., 1965; and Davis and Ferites, 1970).

Statistical analysis of the obtained data were carried out according to Snedecor and Cochran (1980). LSD test was used for mean separation at the $5 \%$ of probability.

\section{RESULTS AND DISCUSSION}

\section{1- Palm morphology:}

1.1- Trunk diameter $(\mathrm{cm})$ :

The minimum trunk diameter was recorded with Ammry $(21 \mathrm{~cm})$ while the maximum trunk diameter was recorded with Hayani $(31 \mathrm{~cm})$. The 
statistical analysis of this attribute indicated that the differences among studied cultivars were insignificant (Table 1). Ibrahim and Kholif (1998) mentioned that trunk diameter varied from $40-90 \mathrm{~cm}$ according to cultivars and field service operations.

\section{2- Number of bunches / palm tree:}

The bunch number varied from 8.22 bunches with Samany to 15.33 bunches with Ammry. Statisticaly, Samany had the minimum bunches number / tree, but no significant differences were occurred in comparison with Zaghloul and Hayani. While Ammry had the maximum, there was no significant difference in comparison with Bint Aisha (Table 1). Salem and Hamdy (1993) reported that number of bunches / palm varied from 9-16.

\section{3- Number of fruits / stalk:}

The number of fruits in each stalk ranged from 11.63 for Zaghloul to 19.04 fruits / stalk for Agglany. However, the differences among Zaghloul, Samany, Hayani, and Bint Aisha cultivars were insignificant. On the other side the differences among Agglany, Ammry, Bint Aisha, Hayani and Samany cultivars were insignificant (Table 1).

\section{4- Weight of fruit stalk $(\mathrm{g})$ :}

The minimum weight of the fruit stalk was 166.04 (g) for Bint Aisha, but the differences among Bint Aisha, Zaghloul, and Agglany cultivars were insignificant. On the other side, the maximum weight of the fruit stalk was 304.22 (g) for Samany, but the differences between Samany, Hayani and Ammry cultivars were insignificant (Table 1). These results agreed with those of Abdalla et al. (1995), who reported that bunch weight ranged from 9.91 . $15.5 \mathrm{~kg} / \mathrm{palm}$ for some date palm cultivars.

\section{5- Length of fruit stalk $(\mathrm{m})$ :}

The length of the fruit stalk varied from the shortest of $0.57(\mathrm{~m})$ in Zaghloul with insignificant difference with Samany $(0.72 \mathrm{~m})$, to the longest of $1.82(\mathrm{~m})$ in Agglany. There were various statistical relationships as shown in Table (1). Ibrahim and Kholif (1998) mentioned that fruit stalk length varied according to cultivar $(0.25-2.00 \mathrm{~m})$.

\section{6- Number of fruit stalks / bunch:}

The maximum number of fruit stalks/ bunch was recorded with Agglany (118.00 fruit stalks/ bunch). No significant differences occurred among all the other five studied cultivars (Table 1). Ibrahim and Kholif (1998) mentioned that the number of fruit stalks/ bunch varied from $33-99$.

\section{7- Total yield ( $\mathrm{kg} /$ palm):}

The data of table (1) shows that Agglany was statistically superior among all studied cultivars concerning the total yield (333.95 $\mathrm{kg} / \mathrm{palm})$. Contrarily, Zaghloul had the lowest total yield (141.77 kg / palm) but no significant differences occurred in comparison with Samany and Bint Aisha. These results were in harmony with those of Ibrahim et al. (2001) who reported that total yield ranged from $142.84-308.16 \mathrm{~kg} / \mathrm{palm}$.

\section{2- Leaf morphology:}

\section{1- Leaf length $(\mathrm{m})$ :}

Leaf length ranged from $3.71(\mathrm{~m})$ in Agglany, which was shorter than other five cultivars, to $4.43(\mathrm{~m})$ in Zaghloul, which was longer than other five 
cultivars. However, differences among the studied cultivars were insignificant (Table 2-a).

2.2- Blade width (m):

2.2.1- Blade width at basal region:

The data of table (2-a) shows that Zaghloul had a statistical minimum blade width at the basal region $(0.38 \mathrm{~m})$. The differences were significant in comparison with Samany and Hayani, however differences were insignificant in comparison with the other cultivars. Likewise, there was no significant difference between Samany and Hayani cultivars. On the other side, there were no significant differences among Agglany, Ammry and Bint Aisha cultivars.

\subsection{2- Blade width at middle region:}

Bint Aisha had a minimum blade width at middle region $(0.33 \mathrm{~m})$ in comparison with Samany, which had a maximum width $(0.46 \mathrm{~m})$ and the difference was significant. However, the differences were insignificant between Bint Aisha and the other studied cultivars (Table 2-a).

\subsection{3- Blade width at apical region:}

The significant maximum blade width at apical region was correlated with Agglany $(0.20 \mathrm{~m})$. No significant differences occurred among other five studied cultivars in regard to this trait (Table 2-a).

\section{3- Length of spines zone $(\mathrm{m})$ :}

The significant maximum spines zone length was correlated with Samany $(0.78 \mathrm{~m})$. No significant differences were found among the other five studied cultivars in regard to this trait (Table 2-a).

\section{4- Length of pinnae zone $(\mathrm{m})$ :}

Zaghloul and Samany had the maximum pinnae zone length (3.57 and $3.52 \mathrm{~m}$, respectively) without significant difference. Also, there were no significant differences between Hayani, Ammry and Bint Aisha cultivars (Table 2-a). On the other hand, Agglany had the significant minimum pinnae zone length $(3.02 \mathrm{~m})$ in comparison with Zaghloul and Samany cultivars.

2.5- Number of spines on both sides of rachis:

The data of table (2-a) indicates that Samany had a significantly higher number of spines on both sides of the rachis (32.33 spines) in comparison with all other studied cultivars, which had statistically insignificant differences among them.

\section{6- Number of pinnae on both sides of rachis:}

The data recorded in table (2-a) indicates that Zaghloul had significantly more pinnae on both sides of the rachis (227.67 pinnae), but no significant difference existed in comparison with Samany. No statistical differences had found among all other studied cultivars.

\section{7- Length of spine $(\mathrm{cm})$ :}

Samany had the longest spines $(14.56 \mathrm{~cm})$ in comparison with all other studied cultivars and the differences were significant. Agglany came second in regard for this trait $(12.23 \mathrm{~cm})$, but no significant differences existed between Hayani and Zaghloul. On the other side, Bint Aisha had the shortest spines $(9.50 \mathrm{~cm})$, but no significant differences found in comparison with Ammry and Zaghloul cultivars (Table 2-b). 


\section{8- Length of pinna $(\mathrm{cm})$ :}

\subsection{1- Length of pinna at basal region:}

The data of table (2-b) shows that Hayani had the longest pinna at the basal region of the blade $(56.29 \mathrm{~cm})$, without significant differences in comparison with Agglany, Bint Aisha and Samany cultivars ( 52.57, 52.30 and $55.02 \mathrm{~cm}$, respectively). Contrarily, Zaghloul had the shortest pinna at the basal region of the blade $(45.13 \mathrm{~cm})$ without significant difference in comparison with Ammry $(46.59 \mathrm{~cm})$.

\subsection{2- Length of pinna at middle region:}

Samany had the longest pinna at the middle region of the blade $(61.73 \mathrm{~cm})$, but no significant differences existed in comparison with Zaghloul, Hayani and Agglany. On the other hand, Ammry had the shortest pinna at the middle region of the blade $(50.34 \mathrm{~cm})$ with insignificant differences in comparison with Bint Aisha and Agglany (Table 2-b).

\subsection{3- Length of pinna at apical region:}

Hayani had a significantly longer pinna at the apical region of the blade $(36.39 \mathrm{~cm})$ than the other cultivars studied. Ammry had the shortest pinna at the apical region of the blade $(23.07 \mathrm{~cm})$ with insignificant differences in comparison with Samany. No statistical differences found among all other studied cultivars, (Table 2-b).

\section{9- Ratio of pinnae zone : spines zone:}

The highest value of this ratio was associated with Ammry (7.61). However, the differences among all studied cultivars were insignificant (Table 2-b).

2.10- Width of pinna $(\mathrm{cm})$ :

2.10.1- Width of pinna at basal region of blade:

The smalles width was correlated with Bint Aisha $(0.82 \mathrm{~cm})$, but no significant differences existed in comparison with Zaghloul and Ammry. On the other side, the largest width was concomitant with Samany $(1.07 \mathrm{~cm})$, but no significant differences found in comparison with Agglany, Hayani and Ammry cultivars $(1.06,1.00$ and $0.95 \mathrm{~cm}$, respectively) (Table 2-b).

\subsection{2- Width of pinna at middle region of blade:}

The largest pinna width at the middle region of the blade was concomitant with Agglany $(3.19 \mathrm{~cm})$, but no significant difference existed in comparison with Samany $(2.84 \mathrm{~cm})$. On the other side, the smallest value of this trait was correlated with Ammry $(2.21 \mathrm{~cm})$ with insignificant difference in comparison with Zaghloul $(2.59 \mathrm{~cm})$, (Table 2-b).

\subsection{3- Width of pinna at apical region of blade:}

Hayani was significantly larger than all other studied cultivars when comparing this attribute $(1.95 \mathrm{~cm})$. On the other side, Zaghloul had the smallest value of this attribute $(1.02 \mathrm{~cm})$, but no significant differences found in comparison with Agglany, Samany and Bint Aisha cultivars (Table 2-b).

2.11- Ratio of pinna length: pinna width:

2.11.1- Ratio of pinna length: pinna width at basal region of blade:

The data of table (2-c) indicates that Bint Aisha had the highest value of this ratio (66.52), but it was not significantly different to Hayani (57.42). The lowest ratio of pinna length: width at the basal region of the blade was 
associated with Agglany (50.16), but no significant differences existed in comparison with Samany, Ammry, Zaghloul and Hayani.

2.11.2- Ratio of pinna length: pinna width at middle region of blade:

Ammry had the highest ratio (23.76). However, it did not statisticaly differ from Zaghloul, Hayani and Samany. Contrarily, the lowest ratio was associated with Agglany (19.02), but no significant differences were seen in comparison with Bint Aisha and Samany cultivars (Table 2-c).

2.11.3- Ratio of Pinna length: pinna width at apical region of blade:

The data of table (2-c) shows that Zaghloul had the highest ratio of pinna length: width at the apical region (27.30), without significant differences in comparison with Agglany and Bint Aisha. The lowest ratio was associated with Ammry (17.60), but no significant differences existed in comparison with Hayani and Samany.

\subsection{2- Thickness of 10 pinnae $(\mathrm{mm})$ :}

Agglany had the thickest pinna $(1.00 \mathrm{~mm}$ for 10 pinnae), but no significant differences were observed in comparison with Samany, Bint Aisha and Hayani cultivars. Contrarily, the thinnest pinna was correlated with Ammry ( $0.84 \mathrm{~mm}$ for 10 pinnae) followed by Zaghloul, Hayani and Bint Aisha cultivars (Table 2-c).

\subsection{3- Number of pinnae at blade apex:}

The blade of Samany had a pair of pinnae at the end, while the other five studied cultivar blades terminated witha single pinna. However, this attribute did not statisticaly analysed. (Table 2-c).

2.14- The angle between pinna and rachis $\left(^{\circ}\right)$ :

The narrowest angle between pinna and leaf rachis was associated with Bint Aisha $\left(18.53^{\circ}\right)$, but no significant differences found in comparison with Agglany and Samany. Contrarily, the widest angle was associated with Ammry $\left(24.35^{\circ}\right)$, but it was not significantly different from all other studied cultivars except Bint Aisha (Table 2-c).

\subsection{5- Weight of leaf $(\mathrm{kg})$ :}

The heaviest leaf weight was concomitant with Samany $(3.01 \mathrm{~kg})$. Contrarily, the lightest leaf weight was concomitant with Ammry $(1.68 \mathrm{~kg})$, but no significant difference was existed in comparison with Zaghloul (Table 2-c).

\section{3-Fruit morphology:}

\section{1- Fruit colour:}

The results indicated that five colours were observed for ripened fruits of the studied cultivars. They were bright yellow (1) for Agglany, yellow with red spots (2) for Samany, orange (3) for Ammry, bright red (4) for Zaghloul and red - scarlet (5) for Bint Aisha and Hayani. No statistical analysis was run for colour trait (Table 3 )

\section{2- Fruit diameter $(\mathrm{cm})$ :}

\subsection{1- Fruit diameter at base:}

Results showed that Ammry had the maximum diameter at the fruit base $(1.05 \mathrm{~cm})$ but no significant differences appeared in comparison with Zaghloul and Samany. The minimum diameter at the fruit base was associated with Bint Aisha $(0.71 \mathrm{~cm})$ but it was not significantly different than Agglany (Table 3). 


\subsection{2- Fruit diameter at middle:}

The data of table (3) shows that Samany had the largest diameter at the fruit middle $(1.42 \mathrm{~cm})$. The smallest fruit diameter at the middle region was found in Agglany. But this was not significantly different in comparison with Bint Aisha (Table 3).

\subsection{3- Fruit diameter at apex:}

Zaghloul had the largest diameter at the fruit apex $(0.70 \mathrm{~cm})$, however Hayani was not significantly different than Zaghloul. Contrarily, Agglany had the smallest fruit diameter at the apical region $(0.53 \mathrm{~cm})$, but no significant difference found in comparison with all other studied cultivars except Zaghloul (Table 3).

\section{3- Fruit weight (g):}

Table (3) indicates that Samany had the highest fruit weight $(20.80$ g), but there no significant differences appeared in comparison with Zaghloul and Hayani. Contrarily, Bint Aisha had the lowest fruit weight $(11.06 \mathrm{~g})$, but it was not significantly different than Agglany. Other statistical differences are shown in table (3).

\section{4- Fruit length $(\mathrm{cm})$ :}

The longest fruit had found with Zaghloul, Ammry Samany and Hayani (5.21, 5.14, 5.05 and $4.87 \mathrm{~cm}$, respectively). The differences among these cultivars were insignificant. The shortest fruit had found with Bint Aisha $(3.69 \mathrm{~cm})$, but no significant difference appeared in comparison with Agglany (Table 3).

\section{4- Female spathe inflorescence morphology.}

\section{1- Length of spathe $(\mathrm{cm})$ :}

The longest spathe was associated with Zaghloul $(88.71 \mathrm{~cm})$. Contrarily, the shortest spathe had found with Hayani $(51.20 \mathrm{~cm})$, but it was not significantly different than Agglany, Ammry and Bint Aisha cultivars (Table 4).

\section{2- Width of spathe $(\mathrm{cm})$ :}

Samany had the widest spathe $(11.23 \mathrm{Cm})$, followed by Agglany and Hayani (9.72 and $9.44 \mathrm{~cm}$, respectively) without significant difference. Contrarily, Ammry had the narrowest spathe $(6.11 \mathrm{~cm})$. Likewise, data indicated that Agglany and Hayani statisticaly had the same spathe width (9.72 and $9.44 \mathrm{~cm}$, respectively) (Table 4).

\section{3- Spathe length: width ratio:}

Zaghloul had the highest ratio of spathe length: width (13.70) in comparison with all other studied cultivars. Contrarily, Samany had the lowest ratio (5.18), but the differences were insignificant when compared with the values of Hayani and Agglany (5.40 and 5.59, respectively). Statistically, Ammry and Bint Aisha came in the middle range between these extremes (Table 4).

\section{4- Spathe indumentum:}

The spathe fuzz density was moderately fuzzy in all studied cultivars except in Agglany, which was sparsely fuzzy. This attribute did not statisticaly analysed (Table 4). 
5- Seed morphology:

5.1- Seed length $(\mathrm{cm})$ :

The differences in seed length of all studied cultivars were insignificant, (Table 5).

\section{2- Seed diameter (cm):}

Samany was had significantly larger seed diameter compared to all other studied cultivars $(0.98 \mathrm{~cm})$, while Bint Aisha had the smallest $(0.79 \mathrm{~cm})$. Other statistical differences among the seed length of the studied cultivars were found (Table 5).

\section{3- Seed weight (g):}

The highest seed weight was associated with Samany $(8.17 \mathrm{~g})$, while the lowest seed weight was associated with Bint Aisha $(4.34 \mathrm{~g})$. Other statistical differences among the seed weight of the studied cultivars were found (Table 5).

\section{4- Position of pit:}

Various pit positions were noticed. Some studied cultivars had seeds with a center pit position (1) such as Agglany, Bint Aisha and Zaghloul. Other studied cultivars (Ammry, Hayani and Samany) had seeds with a pit position below center (2). This trait did not statisticaly analysed (Table 5).

\section{6- Fruit quality traits: \\ 6.1- Total sugars $(\%)$ :}

The lowest percentage of total sugars was associated with Samany (48.25\%), but no significant differences were noticed when compared Agglany and Bint Aisha. Contrarily, the highest total sugars percentage was associated with Ammry (77.25\%), but no significant differences were noticed when compared with Zaghloul and Hayani (Table 6).

6.2- Total soluble solids (TSS) (\%):

The percentage of TSS in Zaghloul was lower than the other studied cultivars (33.21\%), but no significant difference appeared in comparison with Samany. Contrarily, the percentage of TSS in Ammry was higher than all of the other five studied cultivars (49.52\%) (Table 6).

\section{3- The $\mathrm{pH}$ value:}

The lowest $\mathrm{pH}$ value (6.42) had seen with Samany, but no significant differences occurred in comparison with Hayani and Zaghloul. Contrarily, the highest $\mathrm{pH}$ value (7.01) was observed with Bint Aisha, but no significant differences found in comparison with Ammry and Agglany (Table 6).

\section{4- Acidity (\%):}

The data presented in table (6) indicates that no statistical differences found among acidity percentage values of all studied cultivars.

\section{5- Total protein (\%):}

The lowest total protein percentage was associated with Samany $(1.33 \%)$. Contrarily, the shighest total protein percentage was associated with Bint Aisha $(2.75 \%)$, but no significant differences appeared in comparison with Ammry, Hayani and Agglany $(2.60,2.32$ and $2.31 \%$, respectively) (Table 6). 
Mostafa A. F. et al.

7- Fruit mineral constituents:

7.1- Nitrogen (\%):

The lowest nitrogen percentage was associated with Samany $(0.26$

$\%)$, however it was not significantly different than Zaghloul. On the other side, the highest nitrogen percentage was associated with Bint Aisha (0.44\%), but no significant differences appeared in comparison with Ammry, Agglany, and Hayani (Table 7).

7.2- Phosphorous (\%):

The data of table (7) indicates that no statistical differences occurred among phosphorous percentage of Zaghlouol, Agglany, Ammry, Bint Aisha, and Hayani cultivars. $(0.07,0.06,0.06,0.05$, and $0.05 \%$, respectively). On the other side, the lowest phosphorous percentage was associated with Sammany $(0.04 \%)$, but no significant differences found in comparison with any other studied cultivars except Zaghloul.

\section{3- Potassium (\%):}

The lowest potassium percentage was associated with Agglany $(0.66$ $\%)$. Contrarily, the highest potassium percentage was associated with Bint Aisha and Samany ( $0.91 \%$ for each), folowed by Hayani and Zaghloul (0.88 and $0.81 \%$, respectively). There were no significant differences among these four cultivars (Table 7).

\section{4- Magnesium (\%):}

The highest magnesium percentage was associated with Agglany $(0.16 \%)$, but no significant difference appeared in comparison with Zaghloul. Contrarily, the lowest magnesium percentage was associated with Samany $(0.11 \%)$, but no significant differences appeared in comparison with Ammry and Bint Aisha (Table 7).

\section{5- Iron (ppm):}

The lowest iron concentration was associated with Ammry (30.24 ppm). Contrarily, the highest iron concentration was associated with Bint Aisha (54.94 ppm), but no significant difference found in comparison with Zaghloul. Other statistical relations had shown in Table (7).

\section{6- Manganese (ppm):}

The lowest manganese concentration was associated with Sammany (10.86 ppm), but no significant difference existed in comparison with Bint Aish. Contrarily, the highest manganese concentration was associated with Agglany (17.54 ppm), but no significant difference found in comparison with Zaghloul and Ammry (Table 7).

\section{7- Zinc (ppm):}

The lowest zinc concentration was associated with Sammany $(8.14$ ppm), but no significant differences existed in comparison with any studied cultivars except Ammry. Contrarily, the highest zinc concentration was associated with Ammry (10.00 ppm), but no significant differences existed in comparison with any studied cultivars except Samany and Zaghloul (Table 7).

\section{8- Copper (ppm):}

No statistical differences had found among the studied cultivars regarding copper concentration (Table 7). 
Thirty four out of thirty seven morphological attributes for leaf, fruit, spathe and seed were submitted to statistical analysis, three attributes were not statisticaly analyzed because they were not numerical traits. Besides, thirteen quality and chemical attributes of fruits of the studied cultivars were statisticaly analyzed. This numerical method has been widely used in addressing taxonomic problems (Mahmoud, 2004). Samany was conceived as a major cultivar and the results indicated that it had distinctive morphological characteristics; the highest blade width at both the basal and middle regions, length of the spine zone number of spines, length of spine, pinna length at the middle region of the blade, width of pinna at the middle region of the blade, weight of leaf, weight of fruit stalk, fruit diameter at the middle region, fruit weight, width of inflorescence spathe as well as seed diameter and weight. These findings were consistent with those found by Mousa (1985).

The Agglany and Ammry cultivars were resembled to each other in their tree morphological attributes. They shared approximately the same diameter of palm trunk, number of fruits in each stalk, weight of fruit stalk, blade width along the main rachis, length of spine zone, length of pinnae zone, number of pinnae on both sides of rachis, spine length, width of pinna at the apical region of blade, length/ width ratio of pinna at the basal region of the blade, pinna thickness, diameter of fruit at the apical region and length of inflorescence spathe. These results support those found by Abdalla (1979 and 1986) and Mousa (1985).

The study indicated that the Hayani and Bint Aisha cultivars have many common morphological attributes. They have similar trunk diameter, number of fruit bunches for each tree, number of stalks in each fruit bunch, number of fruits for each stalk, leaf length, blade width along the main rachis, length of spine zone, length of pinnae zone, number of spines on both sides of rachis, spine length, length/ width ratio of the pinna at the middle region of the blade, width of pinna at the middle region of the blade, pinna thickness, weight of leaf, and fruit colour. The same was found by Ibrahim and Kholif (1998).

On the other hand, the most significant and common morphological attributes were found in Zaghloul cultivar, which differed from all other studied cultivars. It had the shortest fruit stalk, lowest number of spines on both sides of the rachis, highest number of pinnae on both sides of the rachis, shortest pinna length at the basal region of the blade, shortest pinna width at the the apical region of the blade, highest length/ width ratio of pinna at the apical region of the blade, bright red colour fruit, highest diameter of both base and apex of fruit, longest fruit length, longest spathe inflorescence, and highest spathe length/ width ratio. These results were in concordance with results obtained by El-Bakr (1972), Abdalla (1979 and 1986) and Mousa (1985).

Regarding the fruit quality properties and mineral analysis, it was clearly observed that most of results showed highly significant differences among the studied cultivars. Statistical analysis of total sugars content showed significant differences among all studied cultivars, ranged from $48.25 \%$ in Samany to $77.25 \%$ in Ammry. The same results were obtained by Mousa (1981) and Youssef et al. (1998). 
Moreover, it was found that the total acidity percentage differed significantly among the studied cultivars at the ripening stage. Ammry had the lowest acidity percentage content $(0.04 \%)$ and Zaghloul had the highest value $(0.12 \%)$. Approximately the same results were obtained by Sourial et al. (1986).

Crude protein values ranged from $1.6 \%$ in Zaghloul to $2.75 \%$ in Bint Aisha. These results were in agreement with those of Shaheen et al. (1989b), Al-Hooti et al. (1995), Al-Ghamdi (1996b), Khalil (1998) and Youssef et al (1998).

Concerning the macro elements analysis, the data showed that the most abundant element was potassium, in agreement with Nixon and Carpenter (1978). Also, Al-Hooti et al (1995) and Youssef et al. (1998) stated that date cultivars were found to be a good source of potassium (402.8 $1668.6 \mathrm{mg} / 100 \mathrm{gm}$ ).

Magnesium content values ranged from $0.11 \mathrm{ppm}$ in Samany to 0.16 ppm in Agglany. These results are in harmony with those found by Nixon and Carpenter (1978), Ahmed et al. (1995) and Youssef et al.(1998), who stated that date fruit is a moderate source of magnesium quantities.

Among the trace elements, the analysis of data showed that iron was the main element that showed highly significant differences among all studied cultivars. Iron content values ranged from $30.24 \mathrm{ppm}$ in Ammry to $54.94 \mathrm{ppm}$ in Bint Aisha. This result is in concordance with Youssef et al. (1998).

Table 1: Palm tree morphological characteristics of studied cultivars.

\begin{tabular}{|l|c|c|c|c|c|c|c|}
\hline \multirow{2}{*}{ Cultivars } & \multicolumn{7}{|c|}{ Palm tree morphological characteristics } \\
\cline { 2 - 8 } & $\begin{array}{c}\text { Trunk } \\
\text { diameter } \\
\text { (cm) }\end{array}$ & $\begin{array}{c}\text { Number of } \\
\text { bunches/tree }\end{array}$ & $\begin{array}{c}\text { Number of } \\
\text { fruits/stalk }\end{array}$ & $\begin{array}{c}\text { Weight of } \\
\text { fruit stalk } \\
\mathbf{( g )}\end{array}$ & $\begin{array}{c}\text { Length of } \\
\text { fruit stalk } \\
\text { (m) }\end{array}$ & $\begin{array}{c}\text { Number of } \\
\text { stalks/ } \\
\text { bunch }\end{array}$ & $\begin{array}{c}\text { Total } \\
\text { yield } \\
\text { kg/ } \\
\text { palm }\end{array}$ \\
\hline Agglany & 24.0 & 12.67 & 19.04 & 223.37 & 1.82 & 118.00 & 333.95 \\
\hline Ammry & 21.0 & 15.33 & 17.97 & 242.48 & 1.03 & 66.00 & 245.33 \\
\hline Bint Aisha & 23.0 & 13.67 & 17.07 & 166.04 & 0.94 & 81.78 & 185.62 \\
\hline Hayani & 31.0 & 10.78 & 16.93 & 291.45 & 0.80 & 70.67 & 222.03 \\
\hline Samany & 27.0 & 8.22 & 16.83 & 304.22 & 0.72 & 70.00 & 175.05 \\
\hline Zaghloul & 24.0 & 10.89 & 11.63 & 213.41 & 0.57 & 61.00 & 141.77 \\
\hline LSD (0.05) & $\mathrm{N} . \mathrm{S}$ & 2.56 & 5.89 & 76.17 & 0.21 & 20.91 & 43.98 \\
\hline
\end{tabular}

Table 2-a : Leaf morphological characteristics of studied cultivars.

\begin{tabular}{|l|c|c|c|c|c|c|c|c|}
\hline \multirow{2}{*}{ Cultivars } & \multicolumn{7}{|c|}{$\begin{array}{c}\text { Leaf } \\
\text { length }\end{array}$} & \multicolumn{2}{|c|}{\begin{tabular}{c} 
Blade breadth $\mathbf{( m )}$ \\
\cline { 3 - 8 }
\end{tabular}} & $\begin{array}{c}\text { at } \\
\text { base }\end{array}$ & $\begin{array}{c}\text { at } \\
\text { middle }\end{array}$ & $\begin{array}{c}\text { at } \\
\text { opex } \\
\text { ofpines } \\
\text { zone }(\mathbf{m})\end{array}$ & $\begin{array}{c}\text { Length } \\
\text { of pinnae } \\
\text { zone (m) }\end{array}$ & $\begin{array}{c}\text { Number of } \\
\text { spines on } \\
\text { both sides } \\
\text { of rachis }\end{array}$ & $\begin{array}{c}\text { Number of } \\
\text { pinnae on } \\
\text { both sides } \\
\text { of rachis }\end{array}$ \\
\hline Agglany & 3.71 & 0.45 & 0.38 & 0.20 & 0.56 & 3.02 & 22.22 & 206.22 \\
\hline Ammry & 4.04 & 0.44 & 0.39 & 0.09 & 0.45 & 3.42 & 18.03 & 204.88 \\
\hline Bint Aisha & 4.05 & 0.45 & 0.33 & 0.08 & 0.51 & 3.27 & 22.22 & 206.10 \\
\hline Hayani & 3.98 & 0.51 & 0.36 & 0.12 & 0.49 & 3.47 & 22.00 & 177.67 \\
\hline Smmany & 4.36 & 0.53 & 0.46 & 0.08 & 0.78 & 3.52 & 32.33 & 213.78 \\
\hline Zaghloul & 4.43 & 0.38 & 0.40 & 0.10 & 0.57 & 3.57 & 14.22 & 227.67 \\
\hline LSD(0.05) & $\mathrm{N} . \mathrm{S}$ & 0.12 & 0.08 & 0.06 & 0.14 & 0.47 & 4.54 & 18.23 \\
\hline
\end{tabular}


Table 2-b: Leaf morphological characteristics of studied cultivars.

\begin{tabular}{|c|c|c|c|c|c|c|c|c|}
\hline \multirow{3}{*}{ Cultivars } & \multicolumn{8}{|c|}{ Leaf morphological characteristics } \\
\hline & \multirow{2}{*}{$\begin{array}{l}\text { Length } \\
\text { of spine } \\
\text { (cm) }\end{array}$} & \multicolumn{3}{|c|}{ Length of pinna $(\mathrm{cm})$} & \multirow{2}{*}{$\begin{array}{c}\text { Ratio } \\
\text { of pinnae } \\
\text { zone:spines } \\
\text { zone }\end{array}$} & \multicolumn{3}{|c|}{ Width of pinna $(\mathrm{cm})$} \\
\hline & & $\begin{array}{c}\text { at base } \\
\text { of } \\
\text { blade }\end{array}$ & \begin{tabular}{|c|} 
at \\
middle \\
of blade
\end{tabular} & $\begin{array}{l}\text { at apex } \\
\text { of blade }\end{array}$ & & $\begin{array}{c}\text { at base } \\
\text { of } \\
\text { blade }\end{array}$ & \begin{tabular}{|c|} 
at \\
middle \\
of blade
\end{tabular} & $\begin{array}{c}\text { at apex } \\
\text { of } \\
\text { blade }\end{array}$ \\
\hline Agglany & 12.23 & 52.57 & 56.30 & 29.07 & 5.77 & 1.06 & 3.19 & 1.15 \\
\hline Ammry & 9.64 & 46.59 & 50.34 & 23.07 & 7.61 & 0.95 & 2.21 & 1.34 \\
\hline Bint Aisha & 9.50 & 52.30 & 53.97 & 28.98 & 6.54 & 0.82 & 2.72 & 1.29 \\
\hline Hayani & 11.51 & 56.29 & 59.62 & 36.39 & 6.71 & 1.00 & 2.75 & 1.95 \\
\hline Samany & 14.56 & 55.02 & 61.73 & 27.18 & 5.91 & 1.07 & 2.84 & 1.28 \\
\hline Zaghloul & 10.55 & 45.13 & 61.50 & 27.96 & 7.34 & 0.85 & 2.59 & 1.02 \\
\hline $\operatorname{LSD}(0.05)$ & 1.89 & 6.76 & 6.04 & 4.20 & 1.92 & 0.14 & 0.39 & 0.27 \\
\hline
\end{tabular}

Table 2-c: Leaf morphological characteristics of studied cultivars.

\begin{tabular}{|c|c|c|c|c|c|c|c|}
\hline \multirow{3}{*}{ Cultivars } & \multicolumn{7}{|c|}{ Leaf morphological characteristics } \\
\hline & \multicolumn{3}{|c|}{$\begin{array}{l}\text { Ratio of pnna length: pinna } \\
\text { width }\end{array}$} & \multirow{2}{*}{$\begin{array}{c}\text { Thickness } \\
\text { of } 10 \\
\text { pinnae } \\
\text { (mm) }\end{array}$} & \multirow[t]{2}{*}{$\begin{array}{l}\text { Leaf apex } \\
\text { divergence }\end{array}$} & \multirow{2}{*}{$\begin{array}{l}\text { The angle } \\
\text { between } \\
\text { pinna and } \\
\text { rachis }\left(^{\circ}\right)\end{array}$} & \multirow{2}{*}{$\begin{array}{l}\text { Weight } \\
\text { of leaf } \\
\text { (kg) }\end{array}$} \\
\hline & $\begin{array}{l}\text { at base } \\
\text { of blade }\end{array}$ & $\begin{array}{c}\text { at middle } \\
\text { of blade }\end{array}$ & $\begin{array}{l}\text { at apex } \\
\text { of blade }\end{array}$ & & & & \\
\hline Agglany & 50.16 & 19.02 & 26.03 & 1.00 & Single & 21.50 & 2.34 \\
\hline Ammry & 51.54 & 23.76 & 17.60 & 0.84 & Single & 24.35 & 1.68 \\
\hline Bint Aisha & 66.52 & 20.10 & 24.53 & 0.96 & Single & 18.53 & 2.29 \\
\hline Hayani & 57.42 & 22.24 & 18.94 & 0.89 & Single & 23.03 & 2.39 \\
\hline Samany & 50.79 & 21.76 & 20.97 & 0.99 & Pair & 21.76 & 3.01 \\
\hline Zaghloul & 54.25 & 23.27 & 27.30 & 0.86 & Single & 22.05 & 1.98 \\
\hline $\operatorname{LSD}(0.05)$ & 9.55 & 3.19 & 5.01 & 0.12 & --- & 3.38 & 0.59 \\
\hline
\end{tabular}

Table 3: Fruit morphological characteristics of studied cultivars.

\begin{tabular}{|c|c|c|c|c|c|c|}
\hline \multirow{3}{*}{ Cultivars } & \multicolumn{6}{|c|}{ Fruit characteristics } \\
\hline & \multirow{2}{*}{$\begin{array}{l}\text { Fruit } \\
\text { colour }\end{array}$} & \multicolumn{3}{|c|}{ Fruit diameter (cm) } & \multirow{2}{*}{$\begin{array}{l}\text { Fruit weight } \\
\text { (g) }\end{array}$} & \multirow{2}{*}{$\begin{array}{l}\text { Fruit length } \\
\text { (cm) }\end{array}$} \\
\hline & & at base & at middle & at apex & & \\
\hline Agglany & 1 & 0.82 & 1.03 & 0.53 & 11.14 & 4.19 \\
\hline Ammry & 3 & 1.05 & 1.24 & 0.56 & 17.10 & 5.14 \\
\hline Bint Aisha & 5 & 0.71 & 1.09 & 0.57 & 11.06 & 3.69 \\
\hline Hayani & 5 & 0.86 & 1.25 & 0.62 & 18.12 & 4.87 \\
\hline Samany & 2 & 0.98 & 1.42 & 0.61 & 20.80 & 5.05 \\
\hline Zaghloul & 4 & 1.01 & 1.27 & 0.70 & 19.92 & 5.21 \\
\hline $\mathrm{LSD}(0.05)$ & --- & 0.11 & 0.09 & 0.08 & 2.83 & 0.56 \\
\hline
\end{tabular}

Table (4) :Inflorescence morphological characteristics of studied cultivars.

\begin{tabular}{|l|c|c|c|c|}
\hline \multirow{2}{*}{ Cultivars } & \multicolumn{3}{|c|}{ Female spadix inflorescence morphology. } \\
\cline { 2 - 5 } & $\begin{array}{c}\text { Length of } \\
\text { spathe (cm) }\end{array}$ & $\begin{array}{c}\text { Width of } \\
\text { spathe (cm) }\end{array}$ & $\begin{array}{c}\text { Spathe length: } \\
\text { width ratio }\end{array}$ & $\begin{array}{c}\text { Spathe } \\
\text { indumentum }\end{array}$ \\
\hline Agglany & 54.41 & 9.72 & 5.59 & sparsely fuzz \\
\hline Ammry & 56.10 & 6.11 & 9.42 & moderately fuzz \\
\hline Bint Aisha & 56.19 & 7.31 & 7.83 & moderately fuzz \\
\hline Hayani & 51.20 & 9.44 & 5.40 & moderately fuzz \\
\hline Samany & 60.28 & 11.23 & 5.18 & moderately fuzz \\
\hline Zaghloul & 88.71 & 6.67 & 13.70 & moderately fuzz \\
\hline LSD (0.05) & 5.22 & 0.45 & 1.21 & --- \\
\hline
\end{tabular}


Mostafa A. F. et al.

Table 5: Seed morphological characteristics of studied cultivars.

\begin{tabular}{|l|c|c|c|c|}
\hline \multirow{2}{*}{ Cultivars } & \multicolumn{4}{|c|}{ Seed characteristics } \\
\cline { 2 - 5 } & $\begin{array}{c}\text { Seed length } \\
(\mathbf{c m})\end{array}$ & $\begin{array}{c}\text { Seed diameter } \\
(\mathbf{c m})\end{array}$ & $\begin{array}{c}\text { Seed weight } \\
(\mathbf{g})\end{array}$ & Position of pit \\
\hline Agglany & 2.51 & 0.83 & 5.72 & 1 \\
\hline Ammry & 3.04 & 0.91 & 6.37 & 2 \\
\hline Bint Aisha & 2.60 & 0.79 & 4.34 & 1 \\
\hline Hayani & 2.88 & 0.88 & 7.02 & 2 \\
\hline Samany & 2.78 & 0.98 & 8.17 & 2 \\
\hline Zaghloul & 3.03 & 0.89 & 6.23 & 1 \\
\hline LSD (0.05) & N.S & 0.05 & 0.88 & --- \\
\hline
\end{tabular}

Table 6: Fruit quality traits.

\begin{tabular}{|l|c|c|c|c|c|}
\hline \multirow{2}{*}{ Cultivars } & \multicolumn{5}{|c|}{ Fruit quality traits } \\
\cline { 2 - 6 } & $\begin{array}{c}\text { Total } \\
\text { Sugars (\%) }\end{array}$ & $\begin{array}{c}\text { TSS } \\
(\%)\end{array}$ & $\mathbf{p H}$ & $\begin{array}{c}\text { Acidity } \\
(\%)\end{array}$ & $\begin{array}{c}\text { Total } \\
\text { Protein (\%) }\end{array}$ \\
\hline Agglany & 50.93 & 43.00 & 6.74 & 0.05 & 2.31 \\
\hline Ammry & 77.25 & 49.52 & 6.76 & 0.04 & 2.60 \\
\hline Bint Aisha & 52.70 & 43.44 & 7.01 & 0.07 & 2.75 \\
\hline Hayani & 69.46 & 37.20 & 6.44 & 0.05 & 2.32 \\
\hline Samany & 48.25 & 33.82 & 6.42 & 0.10 & 1.33 \\
\hline Zaghloul & 71.28 & 33.21 & 6.51 & 0.12 & 2.08 \\
\hline LSD (0.05) & 10.93 & 3.31 & 0.29 & N.S & 0.41 \\
\hline
\end{tabular}

Table 7: Fruit Chemical analysis.

\begin{tabular}{|l|c|c|c|c|c|c|c|c|}
\hline \multirow{2}{*}{ Cultivars } & \multicolumn{7}{|c|}{ Minerals } \\
\cline { 2 - 9 } & $\mathbf{N}(\%)$ & $\mathbf{P}(\%)$ & $\mathbf{K}(\%)$ & $\mathbf{M g}(\%)$ & $\mathbf{F e}(\mathbf{p p m})$ & $\mathbf{M n}(\mathbf{p p m})$ & $\mathbf{Z n}(\mathbf{p p m})$ & $\mathbf{C u}(\mathbf{p p m})$ \\
\hline Agglany & 0.37 & 0.06 & 0.66 & 0.16 & 38.96 & 17.54 & 9.07 & 5.11 \\
\hline Ammry & 0.39 & 0.06 & 0.79 & 0.12 & 30.24 & 16.71 & 10.00 & 5.67 \\
\hline Bint Aisha & 0.44 & 0.05 & 0.91 & 0.12 & 54.94 & 11.57 & 9.07 & 6.22 \\
\hline Hayani & 0.37 & 0.05 & 0.88 & 0.13 & 39.56 & 13.92 & 9.36 & 5.67 \\
\hline Samany & 0.26 & 0.04 & 0.91 & 0.11 & 46.84 & 10.86 & 8.14 & 6.00 \\
\hline Zaghloul & 0.32 & 0.07 & 0.81 & 0.15 & 49.79 & 17.36 & 8.44 & 5.67 \\
\hline LSD (0.05) & 0.07 & 0.02 & 0.10 & 0.01 & 5.57 & 2.34 & 1.27 & N.S \\
\hline
\end{tabular}

\section{REFERENCES}

Abdalla M. Y. 1979. Studies on some soft date cultivars. M.Sc. Thesis, Faculty of Agriculture, Zagazig University, Zagazig, Egypt.

Abdalla M. Y. 1986. Morphological and chemical studies through flowering and fruiting stages on date palm. Ph.D. Thesis, Faculty of Agriculture, Cairo University, Cairo, Egypt.

Abdalla M. Y.; A. A. Abdel-Aal and A. M. Abd El-Kader. 1995. Evaluation of some local date cultivars grown in the northern part of the delta, Egypt. Zagazig J. Agric. Res., 22 (4): 1065 - 1076.

Ahmed I. A.; A. W. K. Ahmed and R. K. Robinson. 1995. Chemical composition of Date varieties as influenced by the stage of ripening. Food Chemistry, Elsevier Sci. Ltd., 54: 305- 309. 
Al-Hooti S.; J. S. Sidhu H. Qabazard. 1995. Studies on the physiochemical characteristics of date fruits of five UAE cultivars at different stages of maturity. Arab Gulf Journal of Scientific Research. VI, 72: 130 - 134.

Al-Hooti S.; J. S. Sidhu and H. Qabazard.1997.Physiochemical characteristics of five date fruit cultivars grown in the United Arab Emirates. Plant Food for Human Nutrition, (50): 101-113.

Al-Ghamdi A. S. 1996b. Field evaluation of date palm (Phoenix dactyliferta) cultivars produced through tissue culture techniques. 3- Fruit physical properties. Bulletin of Faculty of Agriculture, Univrsity of Cairo, 47 (1): 153- 165.

Al-Yaha Y. 1995. Biotechnology and date palm development, NAKHLATEC Date palm Consulataive Group, Wye College, University of London.

AOAC .1985. Official Methods of Analysis. 14th ed. Washington, DC: Analytical Association of Official Analytical Chemists.

Barreveld W. H. 1993. Date palm products, Agricultural Service Bulletin. FAO. Rome, (101): 216.

Black C. A.; D.D. Evans; Ensminger; J. L. Whiteand and F. E. Clack. 1965. Methods of soil analysis (part I). Am. Soc. of Agron. Food Chem., 41: 1553-1557.

Davis J. and F. Ferites. 1970. Physical and Chemical methods of soil and water analysis. Soil Bulletin No. 10, FAO.

El-Bakr A. J. 1972. The date palm. Al-Ani press, Baghdad, Iraq. (in Arabic). Food and Agriculture Organization of the United Nation Statistics (2003). http://apps.fao.org/page/collections?subset=agriculture

Ibrahim A. M. F. and M. N. H. Kholif. 1998. Date palm production. Second edition. Published by Monshat El Moarf, Alexandria, Egypt. (in Arabic).

Ibrahim A. F.; A. M. Attalla; Amal M. El-Kobbia and Loaila Y. Mostaffa. 2001.II. Physico-chemical characteristics of fruits and pits of some date palm cultivars as affected by cultivars and seasons. Proceeding of th $5^{\text {th }}$ Hortic. Conference, Suez Canal Universwity, Faculty of Agriculture, March $24-28,2001$, Ismailia, Egypt.

Khalil S. A. A. 1998. Studies on some date varieties and its products. Ph.D. Thesis. Food Sci. Technology Dpt., Fac. Of Agric., Moshtohor, Zagazig Univ., Zagazig, Egypt.

Mahmoud M. W. 2004. The role of panicum turgidum in the ecological and socioeconomic rehabilitation of degraded arid ecosystems in Egypt. M.Sc. Thesis, Faculty of Science, Department of Environmental Sciences, University of Alexandria, Egypt.

Ministry of Agriculture, Central Administration of Agricultural Economic, General Administration of Statistics, Horticulture Crop Statistic Department (2001).

Mousa I. A. 1981. Evaluation and studying of some seedling date palms grown in Ismailia Province. M.Sc. Thesis, Faculty of Agriculture, Zagazig University, Zagazig, Egypt.

Mousa I. A. 1985. Studies and evaluations of some local date cultivars grown at Sharkia governorate. Ph. D. Thesis, Faculty of Agriculture, Zagazig University, Zagazig, Egypt. 
Nixon R. W. and J. B. Carpenter. 1978. Growing dates in the United States, Dpt. of Agric. Washington. D.C.

Pregl E.1945. Quantative Organic Micro Anaysis. $4^{\text {th }}$ ed. Chundril London.

Salem M. S. and Z. M. Hamdy. 1993. Evaluation of some Iraqi date cultivars under conditions of upper Egypt. Egypt J. Appl. Sci., 8 (5): 250 - 269.

Sendecor G. W. and W. G. Cochran. 1980. Statistical methods. Oxford and J. B. $H$. publishing $6^{\text {th }}$ edition.

Shaheen M. A.; M. A. Bacha and T. A. Nasr. 1989. Effect of male type on fruit chemical properties in some date palm cultivars. Annals of Agriculture Science, Cairo, 34 (1):265 - 281.

Sourial G. F.; A. S. Khalifa; S. I. Gaffar; A. P. Tawfik and I. A. Mousa. 1986. Evaluation of some selected date cultivars grown at Sharkia Province, Egypt. 2- Chemical composition. 2머 Symposium on the Date Palm, March 3 -6, 1986. K. F. Uni., Al-Hassa, Saudi Arabia, Vol 2: 141- 151.

Youssef M. K. E.; S. H. Abu El Hawa; M. A. Seleim and B. R. Ramadan. 1998. Evaluation of chemical composition of various types of upper Egypt dates. Assuit Journal of Agricultural Sciences, 29 (3): 33-52.

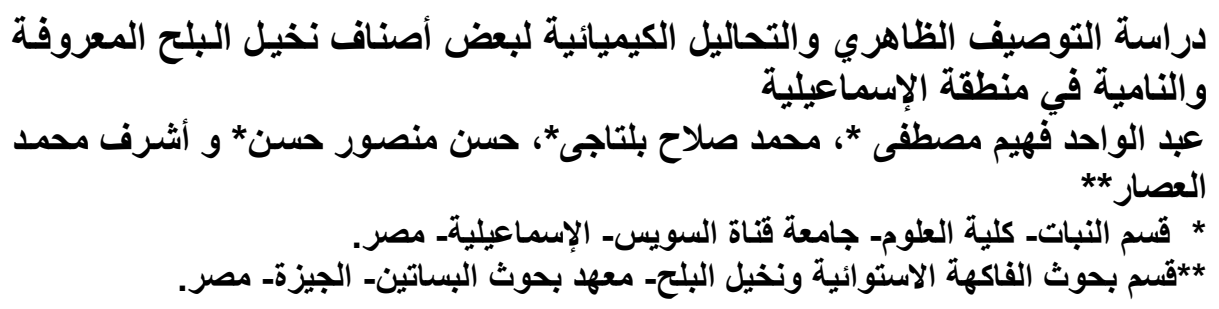

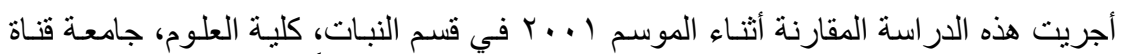

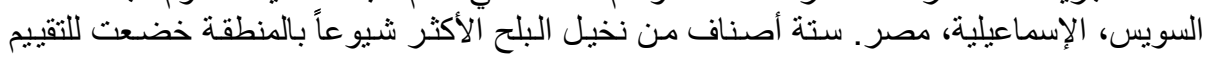

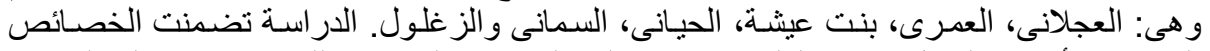

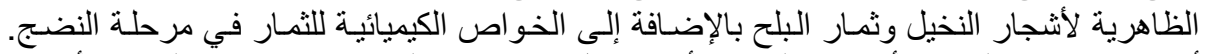

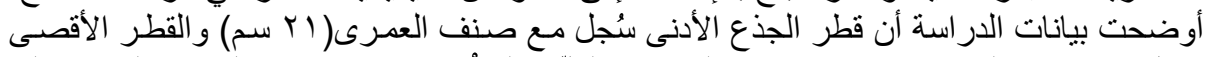

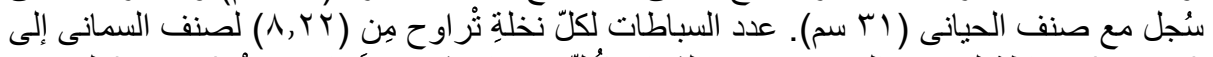

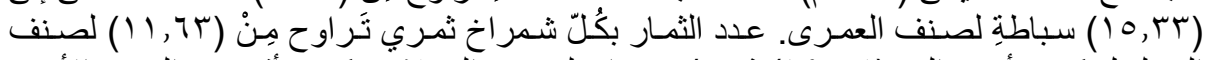

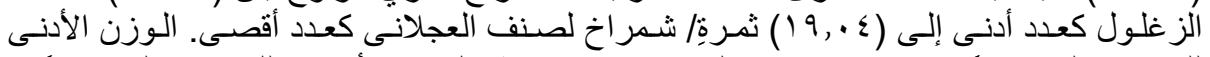

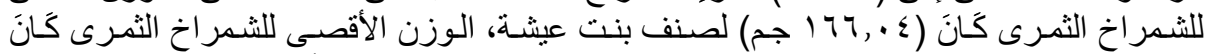

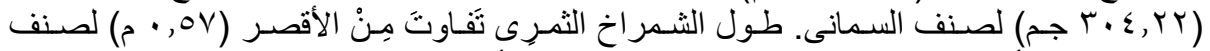

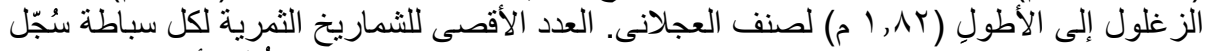

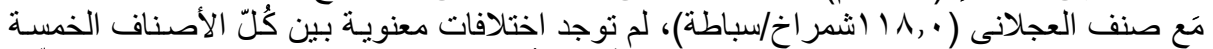

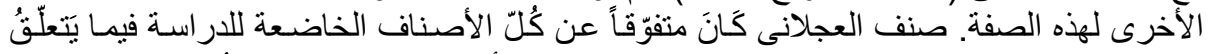

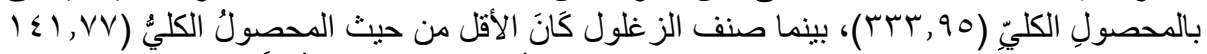

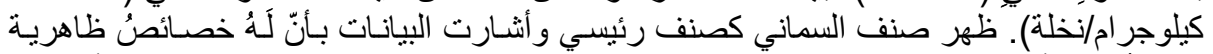

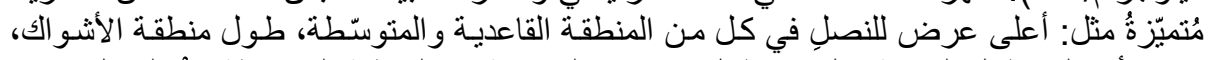

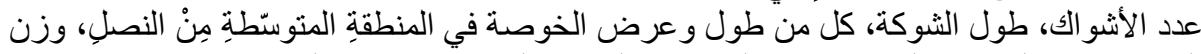

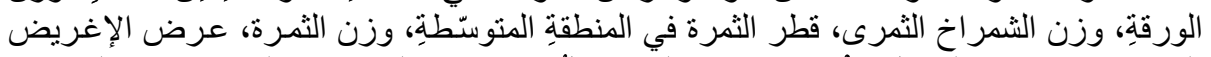

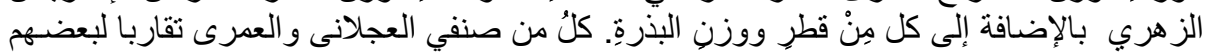




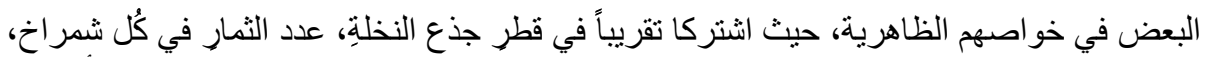

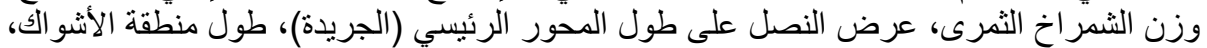

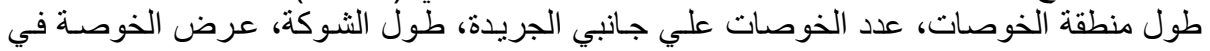

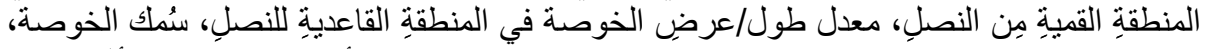

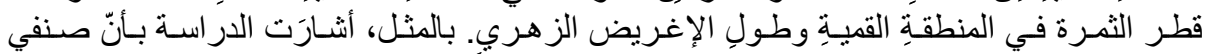

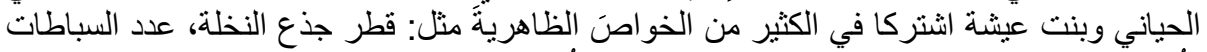

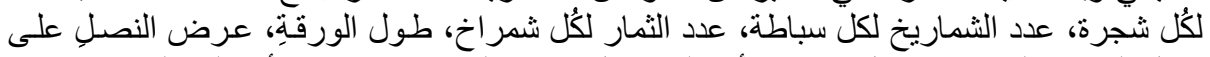

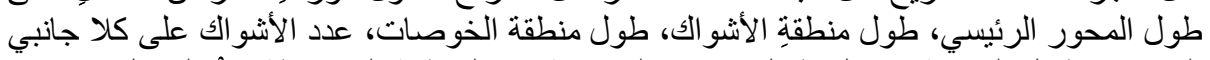

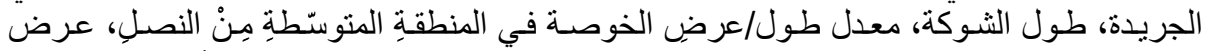

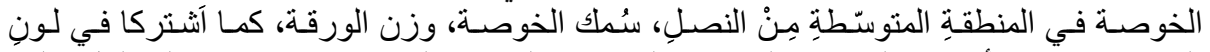

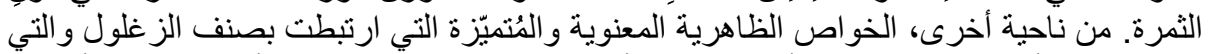

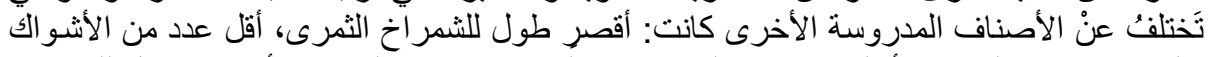

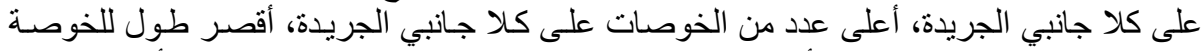

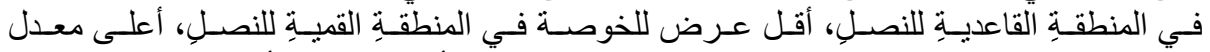

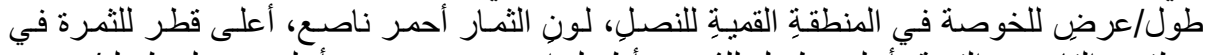

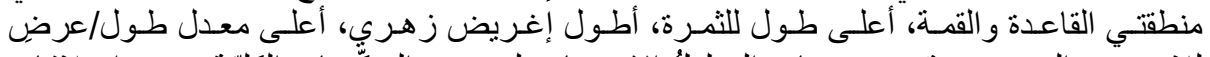

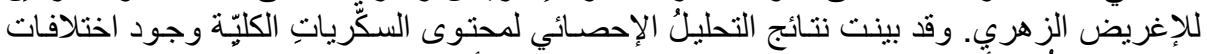

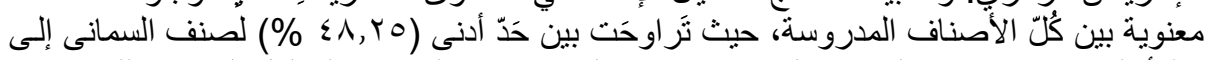

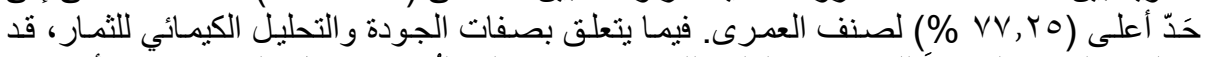

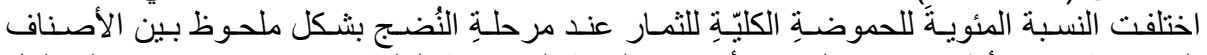

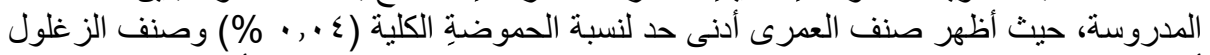

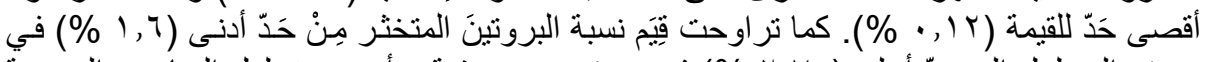

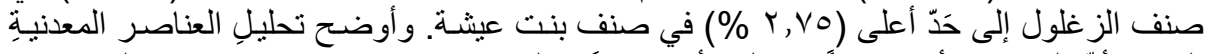

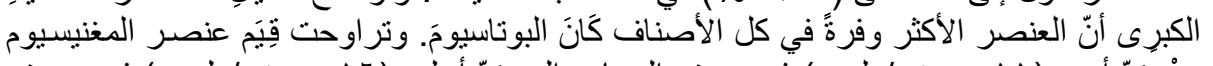

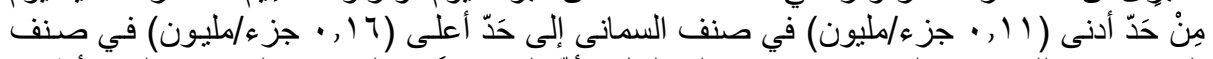

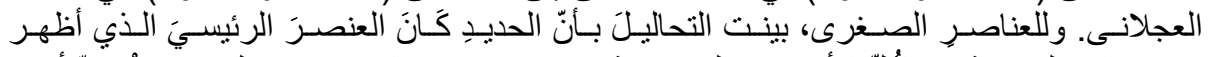

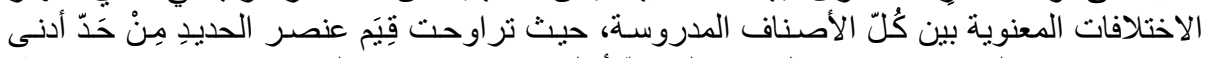

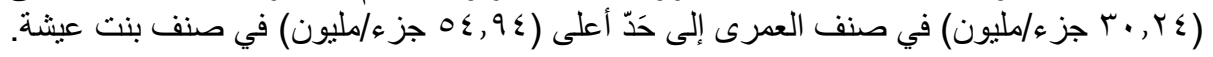

